\title{
Property on Bodily Parts, Dignity and Sovereignty: Some Comparative Reflections on the English and Italian Law of Organ Transplantations
}

\begin{abstract}
This paper aims at giving an account of the status quo of English and Italian law on the complex issue of the legal status of human biological materials, with particular reference to the regulation of organ transplantations. It will begin by arguing that a proprietary framework for bodily parts is not, as some maintain, necessarily incompatible with the respect of human dignity; it will then describe how the law "escapes" this hard issue by separately addressing specific questions rather than using a comprehensive approach; it will conclude by describing how comparative law can be useful to deconstruct existing legal categories and forge new ones.
\end{abstract}

Keywords: legal status of the human body, transplantations, human dignity

\section{Introduction}

The advances of medical science have shown that human biological materials can be used in a variety of ways outside the body. Transplantable organs, gametes, human tissues and stem cells are in great demand from healthcare providers, research institutions and pharmaceutical undertakings, and the immense benefits associated with their utilisation highlight their potential financial value.

Their legal status is, however, debated. What entitlements does the law recognise on such materials? Are they "private property" of the persons they originate from (or their heirs if the former are dead)? Should they be considered as part of the individual's body even after their detachment? Would the recognition of a property relationship inevitably lead to the creation of a market of bodily parts? Would such a market constitute an affront to human dignity? The answer to these questions is essential to define a consistent legal framework for the human body and its parts and to strike an adequate balance between, on the one hand, the need to protect individuals, their autonomy and their beliefs, and on the other hand, the need to supply organs for transplantations and to promote scientific research to develop new therapies and medicines.

In the case of organ transplantations, which will be the main object of this paper, the conflict between these competing interests is particularly stark. In fact, despite the campaigns carried out in many Western countries to encourage donations, the demand of organs largely exceeds the supply. ${ }^{1}$ It is hard to find a living person willing to endanger her

* Ph.D. in Comparative Law, Cultore della Materia, Department of Criminal and Comparative Law, University of Florence, Piazza di San Marco, 4 - 50121 Firenze, Italy.

E-mail: avv.stefano.biondi@gmail.com

${ }^{1}$ Harris, J.-Erin, C.: An Ethical Market in Human Organs, Journal of Medical Ethics, 29 (2003) 3 , 137. The authors suggest the creation of an ethical "monopsomy", where organs can only be purchased by a public body (e.g. the National Health Service) which should ensure vendors are physically fit for the operation and set a fixed, fair price for each organ; the public body would also allocate these for free to patients and create waiting lists based on health needs. 
health by giving an organ; it is also hard to find suitable dead donors, because organs must be in good conditions and must be harvested moments after death; moreover, not all agree (for religious or personal reasons) to their corpse or that of close relatives being "brutalised" for that purpose. ${ }^{2}$

The intrinsic difficulty of reconciling these contrasting claims is reflected in the uncertainty surrounding the legal status of the human body and its parts before and after death. This paper aims at giving an account of the status quo of English and Italian law on this complex issue, with particular reference to the regulation of organ transplantations. It will begin by arguing that a proprietary framework for bodily parts is not, as some maintain, necessarily incompatible with the respect of human dignity; it will then describe how the law “escapes” this conceptual hurdle by separately addressing specific questions rather than using a comprehensive approach; it will conclude by describing how comparative law can be useful to deconstruct existing legal categories and forge new ones.

\section{Commodification of bodily parts and dignity: an irreconcilable antithesis or two facets of the same problem?}

There is a general consensus about the fact that individuals should not be allowed to sell bodily parts. ${ }^{3}$ This has resulted in the Oviedo Convention and Nice Charter provisions (art. 17 and 3, respectively), which prohibit that the human body and its parts "as such" are used as sources of profit, as well as in other domestic provisions of many western legal systems aimed at excluding commercial dealings in bodily parts in at least some circumstances. ${ }^{4}$

The reluctance to view the human body as a marketable commodity has led some authors to the conclusion that detached human tissue and organs should not be considered as "property" of the individual from which they originate, ${ }^{5}$ since this assumption would

2 See Brazier, M.-McGuinness, S.: Respecting the Dead means respecting the living, too. Oxford Journal of Legal Studies, 28 (2008) 2, 297, where the authors argue against the utilitarian view, expressed by the philosopher John Harris, according to whom respecting the dead body is irrational, and any interest in so doing should be overridden by the possibility to save lives (so, organ harvesting should not be subject to the deceased or their families' consent). They claim that in a pluralistic society, which allows freedom of religion and thought, these inherently human feelings and creeds should be respected.

${ }^{3}$ Mason, J. K.-Laurie, G. T.: Mason and McCall-Smith on Law and Medical Ethics. Oxford, 2011. 448.

4 See, inter alia, the Italian Law 91/1999, art. 22.3; the English Human Tissue Act 2004, S.32; the French Code Civil, Art. 16-2; the US National Organ Transplantations Act 1984, Sec. 301.

${ }^{5}$ Inter alia, see Bianca, C. M.: Diritto Civile. Milano, 1989. 163; Munzer, S. R.: An uneasy case against property rights in body parts, Social Philosophy and Policy, 11 (1994) 2, 259; Rao, R.: Property, Privacy and the Human Body, Boston University Law Review, 80 (2000) 2, 359. This latter argues in favour of using a "privacy", rather than a property, paradigm, to define the legal status of the body. She contends that viewing the body as property does not necessarily afford a greater protection to individual choices, for property can be the object of other persons' rights (such as "takings") and can be expropriated in the public interest. She maintains that privacy rights, albeit not unrelated to property (both of them identify a space in which individuals are protected from external intrusions), show a greater connection to the person. 
ultimately lead to consider the whole body, and thus the person to which it "belongs", as a potential "object" of rights-which could be conveyed to others. ${ }^{6}$

On the other hand, others suggest that individual protection can be better achieved if proprietary entitlements on one's own excised bodily parts are recognised, and that this does not necessarily lead to the conclusion that an individual's "whole" body can or should be considered as property. ${ }^{7}$ It should in fact be noted that property rights over a given good do not always encompass the possibility to sell it for financial consideration: the existence of "inalienable" goods shows that proprietary rights can be disconnected from marketability. ${ }^{8}$

Since we are witnessing a "gold rush" to acquire bodily materials, these latter authors consider the exclusionary function of property as the best way to protect individuals from external pressures, maximizing their control over their tissues and enabling them to set conditions for their use by others. For example, recognising a property right over one's own cells might put the individual to whom they "belong" in a position to participate to the profits of a pharmaceutical company that has developed a drug from her own cells; denying such property rights could instead preclude this possibility, which would be particularly odious if the materials had been acquired without obtaining a proper consent from the patient. ${ }^{9}$ Or else, in the context of organ transplants, a recognition of proprietary entitlements

6 This can be partly be attributed to the Kantian assumption that human dignity ("Menschenwürde") is incompatible with the fixing of a price ("Preis"), for it is valued "above all price": "Man cannot dispose over himself, because he is not a thing...for it is impossible, of course, to be at once a thing and a person, a proprietor and a property at the same time" (Kant, I.: Lectures on Ethics. Cambridge, 1997. 157). Kant opposed self-mutilation, which he regarded as an offence to dignity if this harmed the individual (like "partially killing oneself") and the sale of bodily parts: thus, hair could be excised, but their sale was seen as something that could not be seen as completely "free of blame”: see Denis L. (ed.): Kant, I.: Groundworks on the Methaphysics of Morals. Mississagua, 169-170.

${ }^{7}$ Criscuoli, G.: L'acquisto delle parti staccate del corpo umano e i frutti naturali. Rivista (1985) di Diritto della Famiglia e delle Persone 275. Mason, J. K.-Laurie, G.T.: Consent or property? Dealing with the body and its parts in the shadow of Bristol and Alder Hey. Modern Law Review, 64 (2001) 5710.

${ }^{8}$ See Baud, J. P.: L'affaire de la main volée: une histoire juridique du corps. Paris, 1993. 26. In the civil law tradition it has always been accepted that some goods were to be regarded as "res extra commercium"; in Roman Law, these included the res divini iuri ("sacred things"), such as religious or sepulchral objects, the res publicae ("public things"), such as streets or squares, and the res communes omnium ("things common to all"), such as air and waters. Common lawyers instead conceive ownership rights as a bundle of rights-one of which is the right to "profit" or "capital"-which need not exist all at the same time. See below, note 16.

9 Mason-Laurie: op. cit. 728. The authors refer to the famous case of Moore v. Regents of the University of California, 793 P. 2d 479. Mr. Moore, a man affected by leukemia had consented to the removal of his spleen for diagnostic/therapeutic reasons. Unbeknownst to him, the doctors used the spleen's cells to develop (and patent) a pharmaceutical product. Mr. Moore based his damages claim on the tort of conversion (where damages are awarded to the legitimate owner of a chattel which has been used "incompatibly with his rights"-e.g. sold-by a third party); this presupposed a proprietary relation between Mr. Moore and his cells. The Supreme Court of California, reversing the Court of Appeal's judgment, rejected the claim and maintained that no such proprietary relationship existed. Mr. Moore was awarded compensation under the tort of breach of confidence, for he had not fully been informed of the reasons of the spleen's removal. It has been contended that recognizing Mr. Moore's right of property would have been fairer, for he would have been able to take part to the profits generated by the patent. Instead, priority was given to the intellectual property rights of the scientists. 
might make it easier for individuals to control what is done to their bodies or those of their close relatives after death.

These examples show that property over bodily parts might lead to an "offence" to human dignity in some, but not necessarily all, circumstances. This depends essentially on three reasons.

Firstly, human dignity is a concept that is intended in different ways in the bioethical discourse. Some authors ${ }^{10}$ identify two conflicting notions, i.e. an individualistic one, referred to with the expression "dignity as empowerment", ${ }^{11}$ and a communitarian one, referred to with the expression "dignity as constraint": ${ }^{12}$ this explains why dignity is invoked to make the case for opposite solutions to the same moral dilemmas (e.g. the removal of life support from a terminal patient). ${ }^{13}$ Thus, what constitutes an "offence" to dignity will depend on which conception we subscribe to, ${ }^{14}$ for every notion corresponds to a certain vision of the individual and its role in the community (although it can be contended that all conceptions of human dignity aim at safeguarding from "disrespect, insult, humiliation etc... a cherished person, object or value"15) .

Secondly, property is characterised by a wide range of entitlements, which vary in scope and extent and need not exist simultaneously. Honoré described such entitlements as a "bundle of rights", of which marketability is only one. ${ }^{16}$ Therefore, if a fully-fledged

10 Most notably Beyleveld, D.: Brownsword, R.: Human Dignity in Bioethics and Biolaw. Oxford, 2001.

11 That is, dignity as individual empowerment against external interferences, even those aimed at protecting a person "from herself": e.g. being able to refuse life-saving treatment and die "with dignity”.

12 That is, dignity as protection from external pressures, even if that entails a restriction of personal freedom: e.g. a prohibition to enslave oneself, despite being a prima facie limitation of liberty, will prevent weaker individuals from being exploited.

13 E.g. Some invoke human dignity (e.g. a "right to die with dignity") to justify the removal of life support to a suffering terminal patient, while others invoke human dignity (e.g. the "dignity of all human lives") to argue that, in such cases, treatment should not be discontinued.

14 Some authors criticise this approach and maintain that the empowerment (subjective) and constraint (objective) "components" of dignity cannot be separated. In the legal discourse following World War II this concept as has been used with a view of enfranchising individuals from exploitation and external pressures: the inalienability of some rights (e.g. personal freedom) implies a prima facie restriction of one's freedom (I cannot freely decide to enslave myself) but aim at empowering individuals. See Resta, G.: La Dignità. In: Rodotà, S.-Zatti, P (eds): Trattato di Biodiritto. Vol. 1, Milano, 2010. 259, 268-269.

15 Khaitan, T.: Dignity as an Expressive Norm: Neither Vacuous Nor a Panacea. Oxford Journal of Legal Studies, 32 (2012) 1, 1, 4. Interestingly, the etymology of the word dignity also recalls individual status: the Latin word "dignitas" comes from the verb decere ("to be adequate, to be worthy", which originates from the Hindo-European stem dek*, "to consider"); “dignus" ("honourable, worthy [of consideration]") came to be used in association with someone's public office or rank (e.g. "dignitas consolaris", worthiness of the office of Consul), but later, starting from renaissance humanism, it was used to define an inherent quality of all persons, consisting in the ability to autonomously choose whether to pursue the good (Pico della Mirandola, Oratio de hominis dignitate). Kant also viewed dignity as equally intrinsic in all humans (see note 6 above). See Dignità. In: Battaglia, S.: Grande dizionario della lingua italiana. Torino, 1967.

16 Honoré, T. (ed.): Ownership. In: Making Law Bind: Essays Legal and Philosophical. Oxford, 1987. 165. The author identifies the incidents of ownership with the right to possess, to use, to manage (i.e. decide who and how should use the object of property), to the income, to the capital (i.e. to sell or destroy it), absence of term, the duty to prevent harm, liability to execution. 
property right over one's own body leads to inappropriate results (i.e. a market of human biological materials), it is still possible to tailor a modified form of property to the need to protect individuals. ${ }^{17}$

Thirdly, property, like dignity, is also related to and reflects the status of individuals in their community. In the western world, property rights are historically associated with the recognition of legal personality and political rights to a given class of people. ${ }^{18}$

Political liberalism has notably associated liberty and property. In John Locke's words, it is assumed that "every man has a property in his own person", ${ }^{19}$ i.e. one's assets and abilities, that he will trade on the market in order to accumulate the goods he needs to achieve his freely-chosen goals. ${ }^{20}$ By converse, being unable of owning goods or "skills" to exchange impairs one's autonomy, and leads to be excluded from participation to sovereign (i.e. government) powers. ${ }^{21}$ Under this approach, defined as "possessive individualism", property serves the function of marking the boundaries of each person's prerogatives and, more broadly, of enfranchising individuals from dependence on the will of others. ${ }^{22}$ Thus, property rights, which are grounded in the mentioned ownership of the self (self-ownership), become necessary attributes of full legal personhood. ${ }^{23}$

The most significant historical example invoked by liberal (especially feminist) legal and political scholars to prove the strict relationship between property and personhood is the emancipation of women: their changed social and economic role (of workers) in the industrial society led them to claim and obtain political rights, as well as the gradual abolition of the existing limitations to their property rights (especially for married women); ${ }^{24}$

17 Mason-Laurie: op. cit. 728-729.

18 Macpheson, C. B.: A theory of possessive individualism: Hobbes to Locke. Oxford, 1962. The author argues that in liberal capitalistic societies, which assume that individuals are rationally capable to decide what is best for themselves and to pursue their welfare according to their preferences, the ability of being a proprietor and to possess material goods is essential to be fully recognised as a person.

19 Locke, J.: Second Treaty on Government, § 27; London, 1821.

20 This model, which emphasises individual will, represented a change from the situation of Medieval Europe, based on a "static", feudal class system, where birth determined one's place in society. In that context, property rights were centred on regulating access to land, the primary resource in the agricultural economy of the time. Individuals had different prerogatives over it, according to their status (hence the origin of the word estate). This model was no longer compatible with the developing capitalistic economy, propelled by the rising bourgeoisie, which resented the existing aristocratic privileges and restrictions property transferability of (monopolies, fideicomissa, etc.). Political liberalism reversed the property paradigm from one centred on the good to one centred on the owner, his skills, entrepreneurship ingenuity and freedom of choice. See P. Grossi: "La Proprietà e le proprietà nell’officina dello storico”, Quaderni Fiorentini per la Storia del Pensiero Giuridico Moderno,17 (1988) 359, § 12.

21 Macpherson, C. B.: op. cit. 263-264.

22 Ibid.

23 Radin, M. J.: Property and Personhood. Stanford Law Review, 34 (1982) 957, where the author claims that some goods, which she calls "personal property", define our personhood (e.g. nuptial rings or homes), which she distinguishes from "fungible property" (e.g. non-essential, “instrumental” goods).

24 Davies, M.-Naffine, N.: Are Persons Property? Dartmouth, 2001. 80. In particular, the authors refer to the fact that the Common Law doctrine of coverture and of the unity of spouses, regarded husband and wife as "one person in law" and, as a result, the latter lost the ability to control her property, which was taken over by the husband; with the Married Women Property Act 1882, women acquired the right to own, buy and sell their private property as if they were unmarried. 
but the most striking aspect is that women were also afforded an increasing protection of their bodily autonomy, especially in the sexual and reproductive sphere..$^{25}$ This shows that self-ownership, so closely associated with legal personality, is grounded in one's body, and is expressed by the legally sanctioned right to exclude others from it. ${ }^{26}$ Not surprisingly, the right to property has represented the model of civil liberties and fundamental rights at the birth of western constitutionalism. ${ }^{27}$

This view of personhood built on property is criticised, since it accounts only for the patrimonial component of individuality and neglects other facets of human existence: a full rounded idea of person, such as that endorsed by post-war western European constitutions, should transcend the merely economic dimension. ${ }^{28}$ It is nonetheless true, however, that property remains a powerful instrument to protect the person's autonomy and that its exclusionary function appears as essential to enable her to have an active role in a democratic society.

To sum up, property and dignity provide two different perspectives on the same issue, that is, the status of a given person in her political community (thus, her relationship with and participation to sovereign powers); both address the tension between individual and collective prerogatives, which is particularly evident when the "battlefield" is the human body, i.e. the essential and most intimate "component" of human beings, the "instrument" through which persons express themselves, interact with others and engage in any social activity, the main "object" on which political power is exercised ${ }^{29}$ and the ultimate "boundary" between the person and the external world (albeit a "leaky" one, in a "constant state of flux" and interdependency with external factors). ${ }^{30}$

It is thus theoretically possible to define a legal framework for the body and its parts which combines both concepts.

${ }^{25}$ Such as refusing to have sexual intercourse with their husbands, or terminating a pregnancy in some circumstances. Ibid.

26 Dickerson, D.: Property in the Body: Feminist Perspectives. Cambridge, 2007. 8-13. The author claims that the mentioned "gold rush" to acquire human materials has determined a "feminisation" of the human body, now more exposed to external invasions-a feature associated with women's body. Property can thus be an instrument to assert individual "boundaries" and prevent unwanted interferences: it would mark the "enclosure" of a new type of "commons", i.e. the body.

27 Messinetti, D.: Personalità (diritti della). In: Enciclopedia del diritto. Vol. XXXIII, Milano, 1983. 355, at 357.

${ }^{28}$ De Cupis, A.: Sull'equiparazione delle parti distaccate del corpo ai frutti naturali. Rivista trimestrale Diritto e Procedura Civile, 9 (1986) 137. The Italian and German Constitutions responded to the horrors of totalitarianism by re-founding society around the concept of person "both as an individual and in the social groups where human personality is expressed" (art. 2 Italian Constitution) and her dignity (German Constitution, art. 1: "Human Dignity is inviolable").

${ }^{29}$ Foucault, M.: History of Sexuality (Italian translation). Vol. I, Milano, 1978. 120-127. The author claims that changes in the social power assets is reflected in the self-perception of the body and in the constrains it faces.

30 Herring, J.-Chau, P. L.: My Bodies, Our Bodies. Medical Law Review, 15 (2007) 34, 60. 


\section{Gratuity as a way to protect individuals from commodification?}

Before detachment, bodily parts are viewed as “included in the person” rather than as her property. Mason and Laurie point out that the UK House of Lords ruled that one does not "possess, let alone own", her body. ${ }^{31}$ The same can be said of Italian Law: although no statutory authority or court case can be found on the issue, there appears to be a consensus on this matter. ${ }^{32}$

Things are different for detached bodily parts. After being severed, they become distinct entities that may have a significant usefulness; thus, they are liable to become the object of transactions and disputes over who should be entitled to control them. As we shall see, legislators and courts never address the legal status of the body in a comprehensive way, but only regulate/adjudicate on specific uses of different body parts.

The marketability of regenerable bodily parts such as hair or nails, whose detachment does not endanger health, has traditionally been accepted. ${ }^{33}$ The advances of medical technologies rendered things more complex. For example, when transfusions first became possible, blood provision was rewarded financially. ${ }^{34}$ This practice continued until relatively recently in some jurisdictions, although currently many western countries, ${ }^{35}$ encouraged by the WHO, have precluded this possibility by statute. ${ }^{36}$ This fact confirms that blood can in principle be the object of property rights, even though fears of exploitation and the necessity to make transfusions affordable led parliaments to ban its sale. ${ }^{37}$ The language used is that of gratuitous donation, which emphasises solidarity between members of the community, rather than that of property, which recalls "selfish" economic interests; nevertheless, it should be noted that donations imply a proprietary interest in the gifted item.

The gift approach appears to be favoured also when bodily materials are provided to researchers by the person they originate from (often in the name of solidarity and of the need to keep research affordable); quite interestingly however, after researchers have acquired them, the reluctance for the market is replaced by the concern to ensure that such materials are free of claims from others, as these may impair complex and possibly

31 Mason-Laurie: Mason and McCall-Smith on Medical Ethics and Law. op. cit. 448. The authors refer to the case R. v. Bentham, [2005] WLR 1057, where the House of Lords acquitted an individual involved in a robbery who, in order to scare his victims, had used his fingers to "fake" a firearm. His fingers did not fall into the definition of fake weapon (carrying one is an offence) because they were not a distinct object from the robber's body.

32 Bianca: op cit. 163.

33 Herring-Chau: op. cit. 43.

34 See N. 36 below.

35 The WHO reports that of 124 countries which supplied data, 49 had reached $100 \%$ gratuitous donations, of which only 17 were "developing” nations (as of 2006). In the US the donation of blood is free, the donation of plasma can be remunerated. See http://www.who.int/mediacentre/news/ releases/2006/pr33/en/index.html

${ }^{36}$ E.g. in Italy the provision of blood could be paid until financial rewards were banned by art. 12 Law 592/1967, although donors are still entitled to have a paid day off work. In 1975, the World Health Organisation has adopted (a non-binding) Resolution 28.72 to encourage countries to establish transfusions services based on non-remunerated donations.

37 In England, blood was considered property for the purposes of criminal law (see R. v. Rothery, [1976] RTR 550, regarding a blood sample "stolen" from the police station to avoid being prosecuted for drink driving). Similar cases regarding urine and hair also led to the same conclusion $(R . v$. Herbert, [1961] 25 JCL 163 and R. v. Welsh, [1974] RTR 478). 
expensive scientific experiments. This approach has been followed at EU level ${ }^{38}$ and in the US. ${ }^{39}$ In addition, the law generally recognises that detached bodily parts to which a particular art or skill has been applied can be the object of (full) property rights; ${ }^{40}$ it also affords a very strong protection to intellectual property rights on goods developed from human materials, ${ }^{41}$ although recently the Court of Justice of the European Union has provided some exceptions for those developed from embryonic cells. ${ }^{42}$

By contrast, when detached body parts (especially non-regenerable ones) intended for transplantations are at stake all forms of payments for their provision are banned. ${ }^{43}$ As we

38 Tallacchini, M. C.: Cellule e tessuti come terapie avanzate: una biopolitica europea. In: Rodotà-Zatti: op. cit., Vol. 1, Tomo 1, 1063. The author analyses the legal framework of biobanks at Council of Europe and EU level. The discipline is different for materials donated for research and materials donated for other purposes. The former type of donations is addressed only by a non-binding instrument, i.e. Council of Europe's Recommendation 4(2006)Rec, which enables donors to obtain the anonimisation, withdrawal and destruction of donated materials (art. 15). The second type is regulated by Directives 2004/23/EC and 2006/17/EC, on the quality and safety standards "for the donation, procurement, testing, processing, preservation, storage and distribution of human tissues and cells" and Regulation 2007/1394/EC on advanced medical therapies made with the use of human tissue and cells: these encourage tissue donation (Directive 2004/23/EC, Considering 19; Regulation art. 15) but also establish the materials' subsequent marketability by those operators who acquire them (including for-profit biobanks): property is not mentioned but in practice a proprietary regime applies. Conversely, donors forfeit any possibility to control the donated biological materials.

39 In the USA, courts upheld property rights of researchers, but were more hesitant with those of donors. In Moore v. Regents of California (see above, note 9) denied the existence of a proprietary relationship between a man and his removed spleen, but upheld the patent of the institution that had illegitimately appropriated it. In Greenberg v. Miami Children Hospital (264 F. Supp. 2d 1064) the parents of some children affected by a genetic condition agreed to donate tissue and DNA samples for research purposes, from which a patent was later developed; the donors sued the institution, but the court upheld the patent holder's rights maintaining that the plaintiffs had, upon donating the tissues, forfeited any property claim. In Washington University v. Catalona (437 F. Supp. 2d 985) it was established that Washington University was the proprietor of the human tissue stored in its biorepository, which had been donated for research purposes by some patients. The materials had been donated by some of Dr. Catalona's patients for research purposes and stored in Washington University's bio-repository. Since Dr. Catalona had moved to Northwestern University, and wished to continue his research on those materials, he encouraged donors to send Washington University a statement in which they stated they had intended to give their tissues specifically to Dr. Catalona so they should be handed over to him. Washington University sued him.

40 This approach is typical of the Common Law. See R. v. Kelly, [1999] QB 621, or the cases mentioned in the previous footnote, particularly Moore, but also Criscuoli: op. cit.

41 98/44/EC establishes that the human body and its parts, or the discovery of a new element thereof may not be the object of a patent (art. 5.1), but an "element isolated from the human body, or otherwise produced by means of a technical process, including the sequence or partial sequence of a gene, may constitute a patentable invention, even if the structure of that element is identical to that of a natural element" (art. 5.2). The directive also states that certain products, such as the uses of human embryos for industrial or commercial purposes, are not patentable (art. 6.2.C).

42 Case C-34/10, Oliver Bruestle v. Greenpeace e A., which sanctioned that a patent cannot be granted if the product's manufacturing implies the embryo's destruction.

43 See note 4. Directive 2010/45/EU on the safety of organs for transplantation purposes establishes a completely gratuitous EU-wide system. 
shall see in the next chapter, transplantations are meticulously regulated to ensure that no form of exploitation or undue pressure on donors takes place.

Finally, considerable difficulties arise with the legal status of cadavers. Their vilipend or snatching are criminally sanctioned; ${ }^{44}$ the deceased and their families only have limited powers to decide what should be done with the dead body, which are nonetheless offset against the public interest ${ }^{45}$ (e.g. the protection of public health, the performance of autopsies for criminal investigations purposes and, in some countries, ${ }^{46}$ the need to supply organs for transplantation through "presumed consent" schemes).

Before turning to English and Italian law, it is worth observing how this plethora of fragmented rules and policies designed to protect individuals from the risks of commodification do not necessarily reach their aim. Margaret Brazier observes how contradictory it is to deny a patient and her heirs a property right on excised body parts while acknowledging such rights to researchers and doctors: “... Put to the uses of medicine, these body parts become, as if by magic, property, but property owned by persons unknown, for purposes unforeseen... If that represents the law, the law is an ass". ${ }^{47}$

\section{The status of bodily parts and the discipline of transplants in English law}

\section{The status of bodily parts in English Law}

Common Law authorities are ambiguous on the legal status of detached bodily parts. The unlawful appropriation of urine, blood and hair has led to convictions for theft, hence they were deemed as property. ${ }^{48}$

In the case Yearworth $v$. North Bristol NHS Trust, ${ }^{49}$ the claimants were cancer patients who had deposited sperm samples with a specialised hospital unit prior to undergo chemotherapy (a treatment that may cause infertility); the samples were accidentally destroyed by a defective refrigerator, depriving the patients of the chance to procreate. The Court of Appeal awarded compensation in bailment ${ }^{50}$-a remedy which presupposes the claimants' possession of their sperm. ${ }^{51}$ The decision's impact is not clear, for it was not

44 In Italian Law, Criminal Code, art. 410; in English Law, $R$ v. Lynn 2 T R 394 (1788); Human Tissue Act (2004), S.5.

45 In Italy, d.p.r 285/1990 establishes the rules about burials: art. 79 sanctions that cremations must be authorized by the City Mayor on the basis of the deceased's will or a declaration released to cremation associations; lacking this, the spouse or other close relatives must request it; the deceased's wish overrides the relatives'. In England, the executive of the deceased's estate decides about funerary arrangements-the deceased's "advance directives" are not binding (Cremation [England and Wales] Regulations 2008, S.15).

46 E.g. Italy (see Chapter V).

47 Brazier, M: Retained Organs: Ethics and Humanity. Legal Studies, 22 (2002) 4, 550, 563, referring to the Alder Hay and Bristol scandals (see note 67).

48 Herring-Chau: op. cit. 36 . The authors refer to the cases summarized at note 39.

49 [2009] EWCA Civ. 37.

50 Bailment is a contract whereby the bailor transfers a chattel's possession (not its property) to the bailee, who must take reasonable care of it; later the good must be returned. See Bailment in De Franchis, F.: Dizionario Giuridico Inglese-Italiano. Milano, 1984.

51 The basis for the possession rights was that samples had been generated from the claimants, with a view to future use a right included in the "incidents of ownership" described by Honoré. The court noted that limitations to ownership arising from legal provisions (the storage and use of sperm is 
released by a court of last instance and because it was "context-specific"-i.e. only referred to detached parts intended for later use by the "owner". ${ }^{52}$

As for cadavers, an old maxim states that there is "no property in the body" and, although its significance may have been misinterpreted and overemphasised, it made its way in the common law. ${ }^{53}$ In R. v. Kelly and Lindsay, the House of Lords relied on it, but maintained that a dead body, reworked for artistic purposes, was an object of property rights of those who had applied a skill to it (so its unlawful appropriation amounted to theft).$^{54}$ In Dobson v. North Tyneside AHA, ${ }^{55}$ the Court of Appeal denied that the heirs of a woman died at hospital had a property right on her brain, which had legally been removed during the course of an autopsy (the family had asked to perform further tests on it to see whether death had been caused by a negligent misdiagnosis, but the hospital had disposed of it); the judge held obiter that he did not "think" that the pathologist, who had preserved the brain in paraffine (thus applying a skill to it) had acquired its property. ${ }^{56}$ By contrast, in $A B v$ Leeds Teaching Hospital NHS Trust it was held that a hospital which had retained and preserved with sophisticated techniques dead children's organs without their families' consent had acquired their property under the art or skill rule. ${ }^{57}$

Legislative instruments add no clarity to this framework. The most relevant is the Human Tissue Act (HTA) 2004, which regulates the removal, storage and use of human cells, organs and tissue (with the exception of blood, gametes, embryos and embryonic cells, regulated by the Human Fertilisation and Embryology Act 2008 and the The Blood Safety and Quality Regulations 2005). One of its main features is that an administrative authority (the Human Tissue Authority) must licence and supervise each removal, storage and use of bodily materials, including live donor transplantations (S. 32). ${ }^{58}$

Section 1 provides that the removal of human biological materials requires the "appropriate consent" of the person concerned, lacking which it can be provided by a nominated representative or a qualified relative; ${ }^{59}$ without consent it is an offence to proceed (S. 5). However, although the Act refers to "consent", rather than "property" on body parts,

tightly regulated by the Human Fertilisation and Embryology Act 2008) does not eliminate ownership; in the instant case, the defendant's negligence had precluded the claimants from making a legitimate use of the sperm (§ 45).

52 Mason-Laurie: Mason and McCall Smith on Medical Ethics and Law, op. cit. 460, referring to ruling's $§ 28$.

53 Mason-Laurie: Consent or Property, op. cit. 713-714. The authors report that the maxim probably originates from Lord Coke's statement that the body is "caro data vermibus" and is thus "nullius in bonis" (Coke, Inst. 203) or the Haynes case, (1614) 12 Co. Rep. 113, which the authors claim to have stated that corpses cannot own property. The maxim was relied on in subsequent judicial decisions: Williams v. Williams, (1880) 20 Ch. D. 659 at 662-663 stating that one cannot dispose of his body by will because there are no property rights on it.

54 [1999] QB 621.

55 [1997] WLR 596.

56 At $\S 15$.

57 [2004] 2 FLR 365.

58 Except cadaver donations (see below), which are nonetheless supervised by the authority. The authority is composed by experts in the relevant scientific sectors and by lay members, nominated by the Executive.

${ }^{59}$ S. 2 (for minors or dead minors) and S. 3 (for adults or people died in adult age). In the latter case, appropriate consent must be in writing by the donor; lacking this, a nominated representative (S.4); lacking both, a qualified relative. 
it does not exclude the latter: section 32 prohibits “commercial dealings” in human materials removed for transplantation (it makes an offence to give and receive money for an organ's purchase), ${ }^{60}$ thus implicitly admitting that in other cases such transactions (which imply "full" property rights) may be performed; it also provides that "material which is the subject of property because of an application of human skill" is exempted from the prohibition. ${ }^{61}$

In conclusion, the HTA 2004 and the Common Law do not exclude property on detached bodily parts but try to avoid their marketability by the individuals from which they originate.

\section{Live donor transplantations}

When the donor is a living person, the Human Tissue Authority will licence transplantation if it is satisfied that appropriate consent has been provided and no reward has been paid. Live donations are usually directed to specific recipients with whom donors have close relationship: ${ }^{62}$ the dangers for these latter's health make live donations to strangers ${ }^{63}$ quite rare. However, when aspiring donors and recipients are histologically incompatible they may be paired with others with the same problem and with whom they have mutual compatibility so as to "swap" the organs; these may also be "pooled" between multiple donors/recipients, so as to maximise the number of successful transplantations. ${ }^{64}$

\section{Donations from dead donors}

We have seen that the common law establishes that there is no property in a dead body. Nevertheless, before the enactment of the HTA 2004, statute law provided that the person "lawfully in possession of the deceased's body" 65 was entitled to make decisions on organ donations, if, after a reasonable enquiry "as may be practically possible”, she was not aware of any objections of the deceased or the deceased's family; however, failure to make such inquiry was not penalised. ${ }^{66}$

60 This prohibition replicates the one contained in the Human Organ Transplantation Act 1989, Section 7. Before 1989, the sale of organs was not a criminal offence, but it could lead to disciplinary sanctions against the medical professionals involved in the procedure. In the 1980s, a scandal involving Turkish patients brought to the UK only to sell organs led the doctors involved to be disciplined, and one was also struck off the registrar (see Mason-Laurie, op. cit. 545).

${ }^{61}$ Section 1 and 43, respectively.

62 Previously, English Law forbade donations among people who were not genetically related, whereas donations between relatives were unregulated. It seems that the rationale of this prohibition were the minimisation of the risks of organ rejection as well as of financial transactions. This provision was repealed by the HTA 2004. Mason-Laurie: op. cit. 536.

63 I.e. non directed, altruistic donations.

${ }^{64}$ Human Tissue Act 2004 (Persons who Lack Capacity to Consent and Transplants) Regulations 2006, S. 12.

65 If the person had died while hospitalised, the person lawfully in possession of her body would be the hospital itself, so doctors were entitled to make the relevant decisions. If the person had died at home, the body would lawfully be possessed by the household's owners.

${ }^{66}$ Human Tissue Act 1961, Section 1. The law was reformed following the Alder Hay scandal, in which the press reported that a Bristol hospital had an established practice of (legally) harvesting the organs of children, who had died within its premises without notifying their families. 
Following the Alder Hay and Bristol scandals, ${ }^{67}$ Parliament revised the existing legislation and enacted the Human Tissue Act 2004, which repealed those provisions and established that organs can be harvested only when the deceased has provided consent or has appointed a proxy with the authority to do so or, lacking this, if the family has assented. ${ }^{68}$ If consent has not be provided in any of these ways, it cannot be presumed, and materials should not be removed from the body. In theory, if the deceased has opted in favour of donation, and the family opposes, the former's wishes will prevail; however, it is unlikely that doctors will confront grieving families in order to harvest organs. ${ }^{69}$

Unlike donations from living donors, cadaver transplantations are not licenced by the Human Tissue Authority, because the short timing required for the procedure would make it impracticable. This has also led to the enactment of S. 43, which allows those measures aimed at preserving cadavers while ascertaining whether "appropriate consent" has been given. Such measures can be extremely invasive, and may contrast with the individual's religious and cultural prescriptions on dead bodies. ${ }^{70}$

Donations from cadavers cannot be directed at a certain individual and may not be subjected to conditions of any kind: the National Health Service allocates organs according to priority criteria based on health needs. ${ }^{71}$

\section{The status quo of Italian law}

\section{The legal status of bodily parts}

In the 1930s, before the enactment of the current Civil Code (which dates back to 1942), an Italian court, relying on an old scholarly theory, upheld the lawfulness of the sale by a young student's testicle for implantation in an old man eager to become fertile again: ${ }^{72}$ thus, the student had a property right over his detached bodily parts, including the right to sell them. In the 1942 code, a clause was introduced (art. 5) to forbid the acts of disposal of one's body that "cause a permanent impairment of one's physical integrity". ${ }^{73}$ According to

67 Between 1988 and 1995, the organs of children who had died in hospital had been retained (unbeknownst to the families) after autopsies and used for research and for the development of pharmaceutical products. This practice was not illegal under the old statute. The Royal Liverpool Children's Inquiry Report (the Redfern Report). London, 2001.

$68 \mathrm{~S} 3$.

69 Mason-Laurie: op. cit. 551, who observe that S. 40 of the Code of Practice states that it may be inappropriate to proceed in some circumstances so each case should be considered individually.

${ }^{70}$ Many religions do not have a final position on the issue. Some Jewish Orthodox and some Muslim authorities require the body to be buried as quickly as possible and without alterations, while others will view donation favourably; some Shinto and some Confucians are opposed, as well as Romany. See Brazier-McGuinness: op. cit. 307-309.

${ }^{71}$ Mason-Laurie: op. cit. 559.

72 Cass. Pen, 31-1-1934, in (1934) II Foro Italiano 136 (“Caso Salvatori”). The surgeon, who claimed such procedure was effective, was prosecuted for the injuries caused to the student but was later acquitted because the donor had consented to being harmed ("nolenti non fit injuria").

${ }^{73}$ The rationale of this provision can be understood by reading the preparatory works to the code, which was drafted and enacted during the fascist era, when the totalitarian régime pervaded every aspect of society and actively engaged to direct citizens' behaviour so as to satisfy its goals. Art. 5 aimed at preventing self-inflicted injuries to avoid serving in the army, working or procreating. Today, art. 5 must be interpreted in light of the Italian Constitution's person-centred approach: e.g. 
some authors, ${ }^{74}$ the very existence of art. 5 implies a prima facie full property right of individuals on their own detached bodily parts (including the right to sell and destroy them): the only limitation is the possibility to dispose of those materials whose detachment causes a permanent injury. Thus, under this approach, organs and tissue, once excised, become by default property of the person they have originated from. ${ }^{75}$

However, others contend that this approach is "degrading": considering the human body from a merely economic perspective would be incompatible with the Italian Constitution's conception of human being: ${ }^{76}$ persons are not mere owners, let alone producers of goods, but must be considered in all facets of their individuality. In addition, envisaging ownership of one's excised body parts would imply ownership of the whole body. Excised body parts should thus be considered as relinquished objects which third parties may appropriate. ${ }^{77}$

Whatever line of reasoning we follow, Italian law must be viewed in light of the person-centred approach of the 1948 Constitution, focused on the full realisation of individuals and on their dignity's protection. Interestingly, the Constitution affords the right to private property and the right to engage in entrepreneurial activities neither the rank of "inviolable right"78 nor that of "fundamental right"79,80 rather, it emphasises that property must be exercised compatibly with its "social function" and entrepreneurial activities should never offend "human dignity". ${ }^{81}$ Thus, provided that these limits are respected, a property framework for bodily parts is compatible with the Constitution: property is in fact just a means to the end of individual fulfilment.

\section{Donations from living donors}

Living donor transplantations are regulated by different statutes for each type of organ; ${ }^{82}$ all provide a derogation to the general rule of Art. 5 of the Civil Code, allowing permanent impairments to one's physical integrity for the purposes of donation. ${ }^{83}$ Complex procedures, requiring court and medical approval, are imposed to ensure the donor has been informed of the operation's consequences and risks, that consent is genuine and no financial reward is involved in the transaction. ${ }^{84}$ A team of doctors, including the hospital's director, must

vasectomies are now legal because they maximise one's well-being, protected by Constitution's art. 32. See Romboli, R.: Commento all'articolo 5 Cod. Civ. In: Galgano, F. (ed.): Commentario del Codice Civile Scialoja-Branca. Articolo 1-10 Cod. Civ. - Persone Fisiche. Bologna, 1988. 225-43.

${ }^{74}$ Criscuoli: op. cit. 266.

75 The approach has also been followed by the Tribunale di Napoli decision of 14-3-1972, which affirmed the property right of a patient on his cornea removed by an oculist for implantation on another without his consent.

76 See next paragraph below.

77 Bianca: op. cit. 163.

${ }^{78}$ E.g. the right to physical integrity, to one's domicile, to free correspondence.

79 E.g. the right to health.

80 Unlike the German Constitution, whose $\S 14$ proclaims that private property is inviolable.

81 Italian Constitution, art. 41 and 43, located under Title III ("Economic Relations"); most inviolable rights (such as personal freedom, art. 13) are found under Title I ("Civic Relations").

${ }^{82}$ Law 458/1967 (kidneys); Law 52/2001 (bone marrow); Law 483/1999 (partial liver transplant). The first serves as "model”: following statutes recall several of its provisions.

83 E.g. Art. 1 Law 458/1967.

84 Art. 2 Law 458/1967. 
assess the donor's physical and psychological suitability to recover from the operation. Donations among strangers are allowed only if the recipient's close relatives are unavailable or histologically incompatible. The court ${ }^{85}$ ensures doctors have expressed a favourable opinion, that consent has not been induced by undue pressures and that no payment will be performed. It is a criminal offence to act as a facilitator in the sale of organs, but there are no criminal penalties for buyers and sellers.

\section{Donations from dead donors}

Italy has introduced an opt-out scheme for cadaver transplants. Art. 4 of Law 91/1999 provides that the Italian National Health Service shall form a database with a file for each patient, which specifies who is a donor. A formal notification shall be served to all adults, inviting to state whether they wish to be donors after their death, and that consent will be presumed if no reply is provided within 90 days. Implied or express consent may not be overridden by the family, who plays no part in the procedure; it may nonetheless be withdrawn by patients at any time in writing.

This scheme was never put in place because of the high notification costs it would involve. Thus, cadaver transplantations are still regulated by the "transitional" scheme set forth in Art. 23 of Law 91/1999. This consists of a "soft" opt-out scheme: organs can be harvested from the body of those who never objected to being donors, if their families do not oppose in writing; by contrast, if the deceased has expressed her intention to being a donor in her "personal documents" (such as a donor's card) or by notifying the local health authority (all have a donor's register), the family may not oppose.

The constitutionality of both schemes has been criticised by some authors, for they do not adequately take into account the fact that donors might change their minds and be unable to oppose donation in writing (as required by the Law), thus endangering their right to self-determination. ${ }^{86}$

Such a framework seems to suggest that the deceased's family does not have a property right over the corpse; rather, this latter is considered as a common resource that can be used for the public good unless a formal dissent is expressed. ${ }^{87}$ This differs from English law, traditionally based on the power of disposal of the body by those who lawfully "possess" it and now empowering the deceased or the family to decide if the corpse and its parts should be used for transplantation purposes.

However, such powers are limited, for in both jurisdictions cadaver donations cannot be subject to conditions. This differs from living donor transplants where, in spite of the strict procedures and limitations, individuals are afforded some powers to decide the recipient's identity (or, in the case of paired and pooled donations, the identity of one of the procedure's "beneficiaries”). In any case, donations for transplantation purposes imply a relinquishment of all claims on explanted organs.

85 More precisely the "Giudice Tutelare", who is normally in charge of authorizing and supervising the legal activities made on behalf of minors and incompetent people.

${ }^{86}$ For breach of Const. Art. 2, which protects the inviolable rights of the person. See Sommaggio, P.: Il Dono Preteso. Padova, 2001. 155. This approach seems to be at odds with the recent case law regarding the withdrawal of life support from patients in a permanent vegetative state (Englaro Case, Cass. 21748/2007), which, based on the Constitutional rights to dignity and selfdetermination, ruled that decisions must be based on the patients' wishes, which should be inferred by all elements regarding their personality (e.g. religious and philosophical views).

${ }^{87}$ Bianca: op. cit. 164. 


\section{Conclusion. Alternative proposals to define the legal status bodily parts from civil law and common law}

We have seen that the legal status of bodily materials is not clear and that, for policy reasons, regulation varies not only in relation to the different parts but also in relation to the reason why they are used. In addition to being inconsistent, this pragmatic approach shows its limits when, in some circumstances, individuals are not afforded with satisfactory protection.

For this reason, both civil and common lawyers have made proposals to redefine the existing categories while striking an adequate balance between the contrasting claims described above. In particular, the attempts have strived to combine the strong assertion of individual prerogatives given by property rights with the need to protect health and avoid exploitation.

Common lawyers are used to dealing with a "fragmented" notion of property (especially real property), in which ownership and possession may be disconnected; ${ }^{88}$ in addition, real and personal property can be subject to equitable interests, so ownership may carry significant limitations for the benefit of others: working on these concepts, some authors have tried to balance an acceptable set of entitlements for all stakeholders by categorising the human body not as property of the individual, but as a sort of "biocommons" ultimately belonging to the whole humanity. ${ }^{89}$ This would give rise to an obligation to respect it by all, including those to which the body "belong" (they would be stewards of "their own" bodies); it could also justify presumed consent schemes for organ donations. Others have proposed to design the "bio-trust" by considering those who handle bodily parts of others (biobanks, pharmaceutical companies) as trustees, which maintain some obligations towards the owners, i.e. the individuals from which the materials originated: the main concern here is to avoid the disenfranchisement of materials from the source, regarded as inequitable ${ }^{90}$ (and fundamentally unfair).

The civil law notion of property instead has developed from the roman "dominium", which confers its holder an absolute right over the good. However, this concept, albeit "monolithic", is flexible, and its content varies according to the good it refers to. ${ }^{91}$ An interesting proposal was put forward by an Italian author, Francesco Carnelutti, in 1940. He drew a parallel between the concept of "demanio pubblico" ("domaine public", roughly translatable as "public domain") and the status of bodily part. In Italian Law, "demanio pubblico" includes those state properties that, in reason of their connection with important interests, cannot be sold and do not follow the ordinary rules that normally govern the circulation of property. Such goods include, for example, shorelines, beaches, rivers, lakes, public waters, defence buildings. ${ }^{92}$ Their peculiarity is that even their "owner", i.e. the state, has limited powers to dispose of them. Carnelutti proposed that the body and its parts

${ }^{88}$ Such notion reflects the medieval feudal system, based on the personal relations between the sovereign, the different levels of feoffees and the other individuals who had access to land and resources.

89 Campbell, A.: The Body in Bioethics. Abingdon, 2009. 73.

90 Hoppe, N.: Bioequity: Property and the Human Body. London, 2009. 159.

91 Art. 544 of the French civil code: "property is the right to enjoy and dispose of things in the most absolute manner, provided that they are not used in ways prohibited by the law or regulations".

92 Art. 822 Italian Civil Code. 
should be considered as a "demanio privato" (or "private domain”): the individual is their ultimate owner but cannot fully dispose of them in reason of their special significance. ${ }^{93}$

Both equitable entitlements and "demanio privato" define the body as a sort of "public space”, where competing claims are combined, and evoke the connection between body, property and political sovereignty ${ }^{94}$ that we have mentioned in chapter II. $^{95}$ The problem that arises is how the governance of this "space" should be structured. The model represented by the English Human Tissue Authority, which licences the storage and use of materials within a relatively flexible legislative framework, is rather interesting, and could be extended to other circumstances. For example, this ad hoc Authority could be empowered to evaluate whether to authorise controversial or extreme "interventions" on the body, such as assisted suicide, gender re-assignment surgery on a minor or genital female mutilations. ${ }^{96}$ It would be worth, however, to explore ways to combine its technical expertise with a fair representation of the whole society-(including underrepresented categories) in its decisionmaking process, so as to ensure that all views are considered and to avoid that the prerogatives of minorities are not overlooked.

93 Carnelutti, F: Teoria generale del Diritto. Rome, 1940. 315-316.

94 With regards to equity, it is worth to recall how its connection to sovereignty is inherent in its historical development-mitigating the harshness of strict common law rules with "equitable remedies" was a prerogative originally exercised by the Sovereign himself, and later by the Lord Chancellor and by Equity courts. See Zweigert, K.-Kötz, H.: An Introduction to Comparative Law. Oxford, 1998. at section 14).

95 Tallacchini, M. C.: Uno spazio pubblico per i tessuti: oltre la dicotomia autonomia proprietà. In: Rufo, F. (ed.): Il laboratorio della bioetica. Roma, 2011. 50, 78-79.

${ }^{96}$ Even though this latter practice is banned in many western countries and the WHO resolved to eradicate it (See WHO, Department of Reproductive Health and Research, Eliminating Genital Female Mutilations, an Interagency Statement. Geneva, 2008), it is interesting to recall those proposals to combine tradition with the need to protect women by performing an alternative, harmless, merely "symbolic" ritual, involving a small needle puncture on the clitoris which causes an insignificant bloodshed; perhaps, it would be worth discussing whether migrant communities in Western countries could be "licensed" to perform this latter type of rituals, although many oppose as it symbolises male dominance (See Catania, L.-Hussein, O. A. K.: Ferite per sempre. Le mutilazioni genitali femminili e la proposta del rito simbolico alternativo. Roma, 2005). 